\title{
Copper as diagnostic marker of cancers
}

\author{
Magdalena Muszyńska ${ }^{1 *}$, Wojciech Marciniak', Katarzyna Jaworska-Bieniek², Katarzyna Kaczmarek², \\ Grzegorz Sukiennicki ${ }^{2}$, Marcin Lener ${ }^{2}$, Katarzyna Durda², Tomasz Huzarski ${ }^{2}$, Tomasz Byrski ${ }^{2}$, Jacek Gronwald², \\ Oleg Oszurek ${ }^{2}$, Cezary Cybulski ${ }^{2}$, Tadeusz Dębniak ${ }^{2}$, Antoni Morawski ${ }^{1}$, Anna Jakubowska ${ }^{2}$, Jan Lubiński ${ }^{1,2}$
}

From Annual Conference on Hereditary Cancers 2014

Szczecin, Poland. 25-26 September 2014

The study was conducted to determine if serum copper level could be a useful marker for selection for control examinations and if serum copper level is a risk factor in developing cancer.

Copper was quantitatively measured in diluted serum samples by inductively coupled plasma mass spectrometry (ICP-MS) using mass spectrometer (Elan DRC-e, PerkinElmer) in standard mode. In our study, there were two independent groups of patients examined. In the first, retrospective model, there were patients diagnosed with prostate cancer $(\mathrm{n}=166)$ and laryngeal cancer $(\mathrm{n}=123)$ matched with healthy controls. This study showed that serum copper level above $1250 \mu \mathrm{g} / \mathrm{l}$ may be a useful marker for laryngeal examination, but is not a useful marker for prostate cancer early detection. In the second, prospective model, there were patents diagnosed with breast cancer $(n=42)$ matched with unaffected controls. Serum from breast cancer patients was collected 3 - 41 months before cancer diagnosis. This part of study showed that there is a tendency that breast cancer risk is about two times lower when copper serum level is in range between $1035-1311 \mu \mathrm{g} / \mathrm{l}$. Further investigations are needed.

\section{Authors' details}

${ }^{1}$ Department of Genetics and Pathology, International Hereditary Cancer Center, Pomeranian Medical University, Szczecin, Poland. ${ }^{2}$ Read - Gene, S.A., Grzepnica, Poland.

Published: 26 November 2015

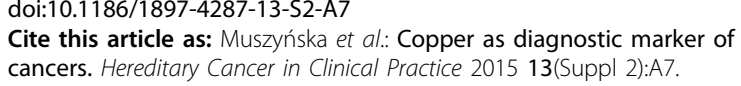

'Department of Genetics and Pathology, International Hereditary Cancer Center, Pomeranian Medical University, Szczecin, Poland

Full list of author information is available at the end of the article
Submit your next manuscript to BioMed Central and take full advantage of:

- Convenient online submission

- Thorough peer review

- No space constraints or color figure charges

- Immediate publication on acceptance

- Inclusion in PubMed, CAS, Scopus and Google Scholar

- Research which is freely available for redistribution

Submit your manuscript at www.biomedcentral.com/submit
() Biomed Central
() Biomed Central

(c) 2015 Muszyńska et al. This is an Open Access article distributed under the terms of the Creative Commons Attribution License (http://creativecommons.org/licenses/by/4.0), which permits unrestricted use, distribution, and reproduction in any medium, provided the original work is properly cited. The Creative Commons Public Domain Dedication waiver (http://creativecommons.org/ publicdomain/zero/1.0/) applies to the data made available in this article, unless otherwise stated. 